\title{
Article \\ Electric Stimulation of Astaxanthin Biosynthesis in Haematococcus pluvialis
}

\author{
Hana-Nur Fitriana ${ }^{1,+}$, Soo-Youn Lee ${ }^{1,+}$, Sun-A Choi ${ }^{2}$, Ji-Ye Lee ${ }^{1}$, Bo-Lam Kim ${ }^{3}$, Jin-Suk Lee ${ }^{1}$ \\ and You-Kwan $\mathrm{Oh}^{3, * \text { (D) }}$ \\ 1 Gwangju Bio/Energy R\&D Center, Korea Institute of Energy Research, Gwangju 61003, Korea; \\ hana3004ap@gmail.com (H.-N.F.); syl@kier.re.kr (S.-Y.L.); jiye.lee@kier.re.kr (J.-Y.L.); \\ bmjslee@kier.re.kr (J.-S.L.) \\ 2 Climate Change Research Division, Korea Institute of Energy Research, Daejeon 34129, Korea; \\ sasv3369@kier.re.kr \\ 3 School of Chemical Engineering, and Institute for Environment \& Energy, Pusan National University, \\ Busan 46241, Korea; bolam@pusan.ac.kr \\ * Correspondence: youkwan@pusan.ac.kr; Tel.: +82-51-510-2395 \\ + These authors contributed equally to this work.
}

check for updates

Citation: Fitriana, H.N.; Lee, S.Y.; Choi, S.-A; Lee, J.; Kim, B.; Lee, J.-S.; Oh, Y.-K. Electric Stimulation of Astaxanthin Biosynthesis in Haematococcus pluvialis. Appl. Sci. 2021, 11, 3348. https://doi.org/ 10.3390/app11083348

Academic Editor: Francesca Scargiali

Received: 17 March 2021

Accepted: 7 April 2021

Published: 8 April 2021

Publisher's Note: MDPI stays neutral with regard to jurisdictional claims in published maps and institutional affiliations.

Copyright: (c) 2021 by the authors. Licensee MDPI, Basel, Switzerland. This article is an open access article distributed under the terms and conditions of the Creative Commons Attribution (CC BY) license (https:// creativecommons.org/licenses/by/ $4.0 /)$.

\begin{abstract}
The green microalga Haematococcus pluvialis accumulates astaxanthin, a potent antioxidant pigment, as a defense mechanism against environmental stresses. In this study, we investigated the technical feasibility of a stress-based method for inducing astaxanthin biosynthesis in H. pluvialis using electric stimulation in a two-chamber bioelectrochemical system. When a cathodic (reduction) current of $3 \mathrm{~mA}$ (voltage: $2 \mathrm{~V}$ ) was applied to H. pluvialis cells for two days, considerable lysis and breakage of algal cells were observed, possibly owing to the formation of excess reactive oxygen species at the cathode. Conversely, in the absence of cell breakage, the application of anodic (oxidation) current effectively stimulated astaxanthin biosynthesis at a voltage range of 2-6 V, whereas the same could not be induced in the untreated control. At an optimal voltage of $4 \mathrm{~V}$ (anodic current: $30 \mathrm{~mA}$ ), the astaxanthin content in the cells electro-treated for $2 \mathrm{~h}$ was $36.9 \%$ higher than that in untreated cells. Our findings suggest that electric treatment can be used to improve astaxanthin production in $H$. pluvialis culture if bioelectrochemical parameters, such as electric strength and duration, are regulated properly.
\end{abstract}

Keywords: microalgae; Haematococcus pluvialis; astaxanthin; electric treatment; stimulation; stress

\section{Introduction}

Astaxanthin (3,3'-dihydroxy- $\beta$-carotene-4,4'-dione) is a common high-value ketocarotenoid pigment ( US $\$ 7150$ per $\mathrm{kg}$ ) involved in various metabolic functions, including anti-oxidative, anti-inflammatory, and immune-stimulatory functions [1,2]. The green microalga Haematococcus pluvialis produces astaxanthin in large quantities ( $4 \%$ of dry cell weight) at the dormant aplanospore (cyst) stage and has been studied extensively as a model strain in research settings as well as in industrial applications [3,4].

Algal astaxanthin synthesis is usually induced as a defense mechanism against environmental oxidative stress $[2,5,6]$. Various stress-inducing conditions, such as nutrient starvation $[7,8]$, exposure to intense light $[9,10]$, high temperatures [11,12], high salinity $[13,14]$, and nanomaterial addition to culture [15], have been applied to increase the content and productivity of algal astaxanthin. Among them, nitrogen-nutrient depletion has been employed extensively for effective astaxanthin induction in $H$. pluvialis cultures [2,16]. However, this approach is time-consuming and associated with a risk of biocontamination from external sources; moreover, it significantly reduces the biomass productivity of $H$. pluvialis [17]. Therefore, the development of an effective astaxanthin induction strategy remains a major challenge in $H$. pluvialis biorefinery approaches. 
Electric stimulation or induction, a relatively new technique in algal biorefinery approaches, involves the application of an electric current to live algal cells through the anode and cathode of a bioelectrochemical system. Recently, Kim et al. [18] treated H. pluvialis seed cells at $100 \mathrm{~mA}$ (voltage: $25 \mathrm{~V}$ ) for a short duration $(1 \mathrm{~min})$ in a singlechamber electrochemical system. After cultivation for seven days, the cell number density of the electro-treated cells increased by $20 \%$, a considerable increase compared to the cell number density of untreated cells, owing to the enhancement of nitrogen consumption and chlorophyll biosynthesis in H. pluvialis cells. However, the intracellular astaxanthin content remained almost constant regardless of the treatment. Recently, we reported the effective induction of triacylglycerols (TAGs) and total fatty acids in Chlorella species by the application of a mild cathodic current of $31 \mathrm{~mA}$ for $4 \mathrm{~h}$, which is a relatively long duration, in a two-chamber bioelectrochemical system [19]. Compared to that in the untreated control, the TAG and total fatty acid contents in electro-treated Chlorella cells increased by $210 \%$ and $24 \%$, respectively. Of note, the astaxanthin and fatty acid biosynthesis pathways are closely related in H. pluvialis, and astaxanthin is present in TAG bodies mostly in monoand di-ester forms with fatty acids $[2,20]$. In connection with the previous study on algal lipids [19], in this study, we aimed to investigate the technical feasibility of using electric stimulation to improve astaxanthin accumulation in H. pluvialis using a two-chamber bioelectrochemical system.

\section{Materials and Methods}

\subsection{Microalga and Photosynthetic Cultivation}

H. pluvialis NIES-144, provided by the National Institute of Environmental Studies (NIES, University of Tokyo, Tokyo, Japan), was used in this study. The NIES-C medium with the following composition (per liter) was used: $0.15 \mathrm{~g} \mathrm{Ca}\left(\mathrm{NO}_{3}\right)_{2}, 0.10 \mathrm{~g} \mathrm{KNO}, 0.05 \mathrm{~g}$ $\beta$-glycerophosphoric acid disodium salt pentahydrate, $0.04 \mathrm{~g} \mathrm{MgSO}_{4} \cdot 7 \mathrm{H}_{2} \mathrm{O}, 0.50 \mathrm{~g}$ trisaminomethane, $0.01 \mathrm{mg}$ thiamine, $0.10 \mu \mathrm{g}$ biotin, $0.10 \mu \mathrm{g}$ vitamin $\mathrm{B}_{12}$, and $3.0 \mathrm{~mL}$ PIV metal solution [21]. One liter of the PIV metal solution contains $1.0 \mathrm{~g} \mathrm{Na}_{2}$ EDTA, $0.196 \mathrm{~g}$ $\mathrm{FeCl}_{3} \cdot 6 \mathrm{H}_{2} \mathrm{O}, 36.0 \mathrm{mg} \mathrm{MnCl} \cdot 4 \mathrm{H}_{2} \mathrm{O}, 22.0 \mathrm{mg} \mathrm{ZnSO} \cdot 7 \mathrm{H}_{2} \mathrm{O}, 4.0 \mathrm{mg} \mathrm{CoCl} 2 \cdot 6 \mathrm{H}_{2} \mathrm{O}$, and $2.5 \mathrm{mg}$ $\mathrm{Na}_{2} \mathrm{MoO}_{4} \cdot 2 \mathrm{H}_{2} \mathrm{O}$. After adjusting the $\mathrm{pH}$ to 7.5 , the medium was filter-sterilized using a $0.2 \mu \mathrm{m}$ membrane (Satorius Stedium Biotech., Göttingen, Germany). For the seed culture, one colony was collected from an agar plate culture of $H$. pluvialis and inoculated in the medium in a $250 \mathrm{~mL}$-scale Erlenmeyer flask with a porous silicon stopper (working volume, $100 \mathrm{~mL}$ ) in a shaking incubator (IS-971RF, Lab Companion, Daejeon, Korea; $25^{\circ} \mathrm{C}$ and $150 \mathrm{rpm}$ ) under continuous illumination (light intensity, $40 \mu \mathrm{mol}$ photons $\mathrm{m}^{-2} \mathrm{~s}^{-1}$ ) [15].

A primary photoautotrophic culture of $H$. pluvialis was established using a $250 \mathrm{~mL}-$ scale funnel-type photobioreactor (f-PBR; working vol., $150 \mathrm{~mL}$ ) using a method optimized previously [22]. H. pluvialis cyst cells collected from the seed flask culture were inoculated in the medium contained in the f-PBR till an optical density (OD) of 0.05 was achieved at $660 \mathrm{~nm}$, as measured using a UV-VIS spectrophotometer (Optizen 2120UV, Mecasys Co., Daejeon, Korea). The f-PBR was continuously supplied with $5 \%(v / v) \mathrm{CO}_{2}$ in air at a rate of $60 \mathrm{~mL} \mathrm{~min}^{-1}(0.4 \mathrm{vvm})$ from the bottom of the reactor. The f-PBR was incubated for 25 days in a plant growth chamber (GC-300, JEIO TECH, Korea; light intensity, $50 \mu \mathrm{mol}$ photons $\mathrm{m}^{-2} \mathrm{~s}^{-1} ; 12 \mathrm{~h}$ light/dark cycle; $25^{\circ} \mathrm{C}$ ). The details of the culture conditions employed have been reported in a previous study [22].

\subsection{Electric Stimulation}

A two-chambered electrochemical reactor (constructed using Lexan polycarbonate materials, each of $110 \mathrm{~mm} \times 110 \mathrm{~mm} \times 25 \mathrm{~mm}$; working volume, $120 \mathrm{~mL}$ ) was used in this study (Figure 1). Carbon cloth electrodes ( $45 \mathrm{~mm} \times 45 \mathrm{~mm}$; FuelCell Co., Brazos County, TX, USA) were used as both the anode and cathode and were connected by a titanium wire. A proton-exchange membrane (Nafion 117, DuPont, Newark, DE, USA) was used to separate the anodic and cathodic chambers. For the electric stimulation experiment, green vegetative $H$. pluvialis cells cultured for 5 days in the f-PBR (cell density, ca. $15 \times 10^{4} \mathrm{~mL}^{-1}$ ) 
were harvested by centrifugation (4000 rpm, $4{ }^{\circ} \mathrm{C}, 5 \mathrm{~min}$; MICRO 17TR, Hanil Science Inc., Daejeon, Korea), washed in $0.1 \mathrm{M}$ sodium phosphate buffer (pH 7.0), resuspended in the same buffer, and then transferred to each compartment of the electrochemical reactor using a sterile disposable hypodermic syringe. The voltage between the anode and cathode was controlled using a DC power supply (GPDX303S, Good Will Instrument Co., New Taipei City, Taiwan). In the cathodic current experiment, the voltage was fixed at $2 \mathrm{~V}$ for 2 days, whereas in the anodic current experiment three different 2, 4, and $6 \mathrm{~V}$ were examined for 1 and 2 days. The cathodic and anodic chambers were continuously aerated at a rate of $48 \mathrm{~mL} \mathrm{~min}{ }^{-1}(0.4 \mathrm{vvm})$ using a sterile syringe filter of $0.2 \mu \mathrm{m}$ (Satorius Stedium Biotech., Göttingen, Germany). All bioelectrochemical experiments were conducted in a temperature-controlled room (ca. $25^{\circ} \mathrm{C}$ ). It was speculated that photosynthetic growth (or cell division) of $H$. pluvialis could not be induced owing to the use of the phosphate buffer during electric stimulation. Details of the bioelectrochemical conditions have been published earlier [19].

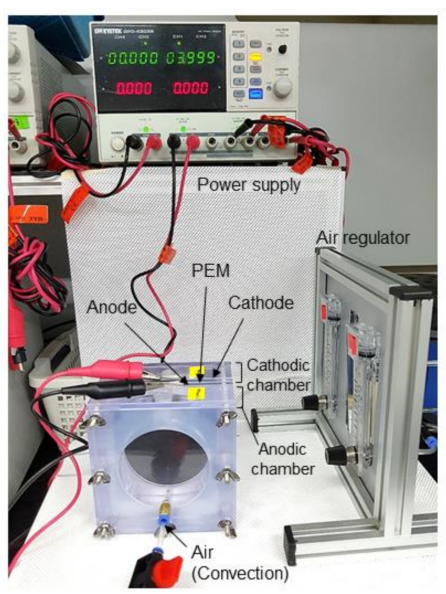

Figure 1. The two-chamber bioelectrochemical system equipped with DC power supply and an aeration control unit [19]. PEM, proton-exchange membrane.

\subsection{Cyclic Voltammetry (CV) Analysis}

Bioelectrochemical reactions between the carbon electrode and $H$. pluvialis cells were characterized using CV analysis at a constant temperature (ca. $25^{\circ} \mathrm{C}$ ). The CV measurements were performed in a $20 \mathrm{~mL}$ single-chamber electrochemical reactor $\left(\mathrm{BASi}^{\circledR}\right.$ Analytical Instruments, West Lafayette, IN, USA) with three electrodes using a potentiostat (CHI $660 \mathrm{E}, \mathrm{CH}$ Instruments Inc., Austin, TX, USA). Glassy carbon (3 mm diameter; $\mathrm{CHI} 104, \mathrm{CH}$ Instruments Inc.), $\mathrm{Ag} / \mathrm{AgCl}$ (3 M NaCl, sat.; Re-6, BASi Analytical Instruments), and a platinum wire (ALS Co., Tokyo, Japan) were used as the working, reference, and counter electrodes, respectively. The potential sweep range and scan rate were $-0.5 \mathrm{~V}$ to $+0.5 \mathrm{~V}$ and $10 \mathrm{mV} \mathrm{s}^{-1}$, respectively. Similar to that in the electric simulation experiment, green vegetative $H$. pluvialis cells cultured for 5 days in the f-PBR were used for CV measurements. The PBR algal cells were centrifuged at $4000 \mathrm{rpm}\left(4^{\circ} \mathrm{C}\right.$ for $5 \mathrm{~min}$; MICRO 17TR, Hanil Science Inc., Daejeon, Korea), washed in fresh NIES-C medium, resuspended in the same medium, and transferred to the electrochemical reactor using a sterile disposable hypodermic syringe. Before the experiment, oxygen dissolved in the medium was removed carefully by supplying the reactor with pure $\mathrm{N}_{2}$ gas (filtered through a $0.2 \mu \mathrm{m}$ membrane) at a flow rate of $2.5 \mathrm{~mL} \mathrm{~min}{ }^{-1}$ for $30 \mathrm{~min}$.

\subsection{Other Analytical Methods}

H. pluvialis cell growth was monitored by measuring the OD and cell number using a UV-VIS spectrophotometer (660 nm; Optizen 2120UV, Mecasys Co., Daejeon, Korea) and a Coulter counter (Multisizer ${ }^{\mathrm{TM}} 4$, Beckman Coulter, Indiana Polis, CA, USA), respectively. The final dry cell weight of the algal cells after cultivation for 25 days was 
determined by filtering $5 \mathrm{~mL}$ of the cell aliquots using pre-weighed GF/C glass microfiber filters (Whatman, UK) and drying at $60^{\circ} \mathrm{C}$ overnight [15]. The morphological features of H. pluvialis cells were observed using bright-field microscopy (Axio Imager.A2, Carl Zeiss, Germany). The $\mathrm{pH}$ value was measured using a $\mathrm{pH}$ meter (DKK-TOA Co., Tokyo, Japan). The light intensity was measured using a quantum meter (Li-250A, Li-COR Inc., Lincoln, NE, USA).

For analyzing astaxanthin production, the $H$. pluvialis cells were harvested by centrifugation (4000 rpm for 10 min; Combi R515, Hanil Science Inc., Daejeon, Korea), doublewashed with purified water, and freeze-dried for 3 days in a freeze-dryer lyophilizer (FD8508, IlShin BioBase Co., Yangju-si, Korea). The freeze-dried cells were stored in a vacuum bag at $-20{ }^{\circ} \mathrm{C}$ until further use. The astaxanthin content was measured using a high-performance liquid chromatography (HPLC) instrument (Agilent 1260 Infinity, Hewlett-Packard, Santa Clara, CA, USA) equipped with a diode-array detector and a YMC Carotenoid column ( $250 \mathrm{~mm} \times 4.6 \mathrm{~mm}, 5 \mu \mathrm{m}$, YMC Inc., Kyoto, Japan), as previously described $[15,23]$. Briefly, ca. $16 \mathrm{mg}$ of freeze-dried H. pluvialis cells and $1.0 \mathrm{~g}$ of glass microbeads were mixed vigorously with $1 \mathrm{~mL}$ acetone for $10 \mathrm{~min}$ at room temperature (ca. $27^{\circ} \mathrm{C}$ ). The mixture was then separated by centrifugation at $8000 \mathrm{rpm}$ for $5 \mathrm{~min}$ (MICRO 17TR, Hanil Science Ltd., Daejeon, Korea). The astaxanthin-containing acetone solution was collected and evaporated using a rotary vacuum evaporator (EZ2 PLUS, Genevac Ltd., Ipswich, UK) at $40{ }^{\circ} \mathrm{C}$ for $30 \mathrm{~min}$. The astaxanthin extract was mixed with $0.2 \mathrm{~mL}$ dichloromethane, $0.8 \mathrm{~mL}$ methanol, and $1 \mathrm{~mL} 0.05 \mathrm{~N} \mathrm{NaOH}$ solution (in freshly prepared methanol). For saponification, the sample was incubated overnight in dark at $4{ }^{\circ} \mathrm{C}$ and then analyzed using HPLC.

\section{Results and Discussion}

\subsection{H. pluvialis Life Cycle and Astaxanthin Induction}

Figure 2 shows the changes in the cell number density and shape of $H$. pluvialis upon culturing for 25 days in the photosynthetic photobioreactor. To enhance astaxanthin production in $H$. pluvialis cells, $1 \mathrm{mM}$ nitrate was used as the nitrogen source. The cell number density of $H$. pluvialis increased almost linearly with time after a short delay period of 2 days (Figure 2a). However, after 15 days of culture, as the nitrate content was depleted, the growth rate of $H$. pluvialis decreased considerably and the culture soon entered a stationary growth phase.
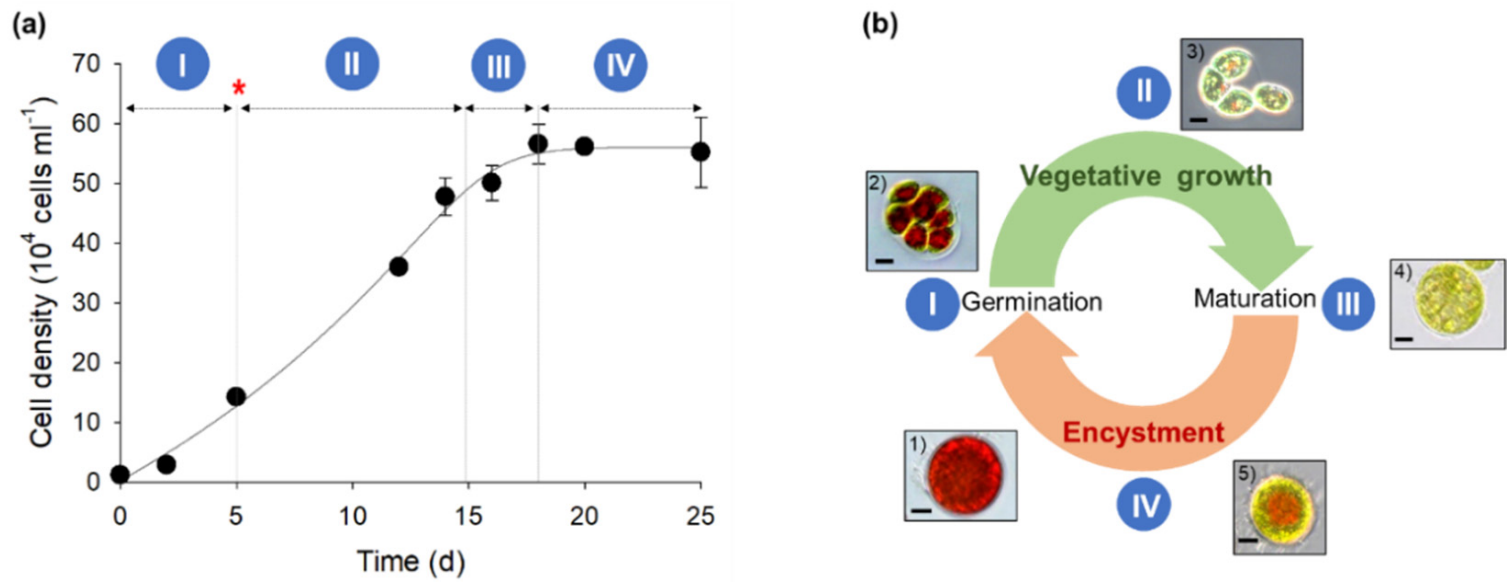

Figure 2. Time course profile of changes in the cell number density (a) and morphology (b) of Haematococcus pluvialis cells during photobioreactor cultivation for 25 days. The life cycle of $H$. pluvialis is characterized by five types of distinguishable cellular morphologies based on microscopic observation: (1) astaxanthin-rich asexual aplanospore; (2) dividing aplanospore with internal differentiated zooids; (3) green vegetative biflagellate cell; (4) green vegetative non-motile palmella; and (5) astaxanthin-accumulating palmella cell. The asterisk $\left(^{*}\right)$ indicates the growth stage of $H$. pluvialis cells used for the electric stimulation experiment. Scale bars in the optical images represent $10 \mu \mathrm{m}$. 
The growth pattern of $H$. pluvialis cells during the 25 day cultivation period could be largely divided into two different stages: vegetative growth (cell division and enlargement), and encystment with astaxanthin induction. More specifically, based on the morphological characteristics observed using optical microscopy, the life cycle of the microorganism was characterized by five distinct cell types (Figure $2 \mathrm{~b}$ ). When the red cysts (cell-type \#1) harvested from the seed flask culture were inoculated in fresh medium contained in the photobioreactor, the cells began to germinate within $6 \mathrm{~h}$. A dividing cyst (cell-type \#2) with the internally differentiated zooids was split open, releasing daughter cells into the external environment. The biflagellate motile cells released (cell type \#3) grew rapidly and became the predominant cell type during the vegetative growth stage. With cell aging, sequentially, the motile cells lost their flagella, expanded in volume, and formed non-motile palmella cells (cell-type \#4). Under conditions of stress, such as nitrogen depletion, intracellular astaxanthin biosynthesis was induced in the palmella cells, which led to brownish-green coloration in the cells (cell-type \#5). Eventually, these cells were transformed into asexual aplanospores enriched in astaxanthin with a characteristic bright red color (cell type \#1).

After the 25 day cultivation period, the specific astaxanthin productivity of $H$. pluvialis in the photobioreactor was estimated to be $2.4 \pm 0.5 \mathrm{mg} \cdot \mathrm{g}-\mathrm{dcw}{ }^{-1} \cdot \mathrm{d}^{-1}$. This result is comparable to that of $H$. pluvialis cells cultured in nitrogen-free medium for 14 days (ca. $2.1 \mathrm{mg} \cdot \mathrm{g}-\mathrm{dcw}^{-1} \cdot \mathrm{d}^{-1}$ ) [24]. However, as specified above, nitrogen depletion requires a significantly long processing time and cannot be considered ideal for designing an economical $H$. pluvialis biorefinery process.

\subsection{Electric Induction of Astaxanthin Production Using Cathodic and Anodic Currents}

Microbial electro-stimulation can be performed by applying either a cathodic or anodic current in a two-chamber electrochemical system (Figure 1). Anodic current stimulation is useful for controlling intracellular redox balance, such as $\mathrm{NAD}(\mathrm{P}) \mathrm{H} / \mathrm{NAD}(\mathrm{P})^{+}$balance, in bacteria [25]. Meanwhile, cathodic current treatment has been reported to stimulate the accumulation of reduced biomolecules, such as TAGs and fatty acids (particularly in Chlorella), via electron transfer and/or reactive oxygen species (ROS) generation from the cathode [19].

In this study, since a mild cathodic current was considered to act as a novel stress inducer for algal astaxanthin biosynthesis, alterations in the morphology and astaxanthin content of $H$. pluvialis were evaluated in the cathodic chamber of the bioelectrochemical system previously optimized for Chlorella lipids [19]. Biflagellate motile H. pluvialis cells cultured for 5 days in the photobioreactor were harvested, resuspended in $0.1 \mathrm{M}$ phosphate buffer ( $\mathrm{pH}$ 7.0), and electro-treated for 2 days at a cathodic current of $3 \mathrm{~mA}$ (voltage: $2 \mathrm{~V}$ ). After incubation for 2 days, regardless of the electric treatment applied, most vegetative H. pluvialis cells were transformed into brown or brownish-green non-motile palmella cells, indicating that astaxanthin biosynthesis was induced, albeit at low levels, within the cells. However, the astaxanthin content of the cells treated at $2 \mathrm{~V}$ reduced by $57 \%$, a

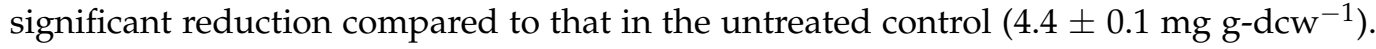
Furthermore, some H. pluvialis cells were damaged (Figure 3). This suggests that unlike in case of Chlorella [19], the cathodic current environment negatively affects the viability and astaxanthin-synthesizing activity of $H$. pluvialis cells.

Considering the severe cell damage induced, we switched from cathodic to anodic current for electric treatment while maintaining other bioelectrochemical parameters. Figure 4 shows the changes in the optical morphology and astaxanthin content of H. pluvialis cells treated for 2 days under anodic current at 2, 4, and $6 \mathrm{~V}$. The untreated H. pluvialis cells remained green for 1 day and turned partially brownish-green after 2 days. Conversely, the electro-treated H. pluvialis cells showed a significant color change to brown on day 1 , indicating the relatively rapid induction of astaxanthin biosynthesis than that in the control. Contrary to the cathodic current results (Figure 3), no significant cell degradation and disintegration were observed at the applied voltages of 2-6 V. Instead, unique morphological changes, such as separation of the cell wall and cytoplasm and secretion of extracellular 
biomaterials (possibly cell wall lysates) occurred in the electro-treated H. pluvialis cells, which tended to worsen as the voltage increased from 2 to $6 \mathrm{~V}$. Nevertheless, at an optimal voltage of $4 \mathrm{~V}$ (current intensity: $30 \mathrm{~mA}$ ), the astaxanthin content was $36.9 \%$ higher

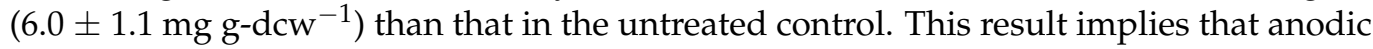
current treatment stimulated astaxanthin accumulation in $H$. pluvialis. However, at a higher voltage of $6 \mathrm{~V}$ (current intensity: $81 \mathrm{~mA}$ ), the astaxanthin content of $H$. pluvialis cells decreased compared to that achieved at $4 \mathrm{~V}$, indicating that an excessively high current does not necessarily induce astaxanthin production in $H$. pluvialis cells.

(a) $0 \mathrm{~V}$
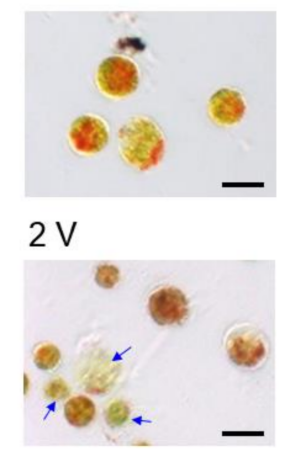

(b)

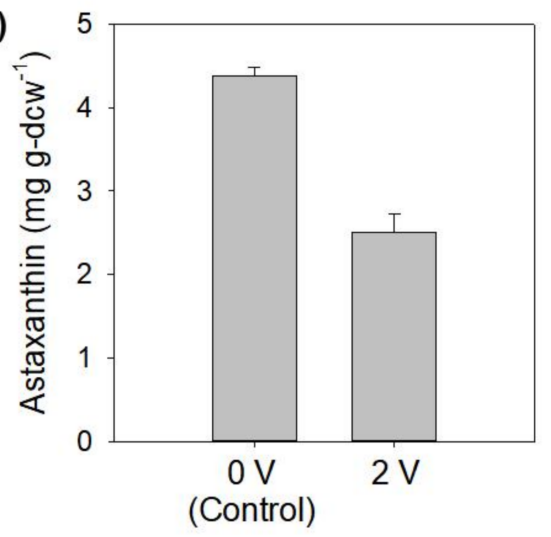

Figure 3. Microscopic image (a) and astaxanthin content (b) in Haematococcus pluvialis cells after electro-treatment at $2 \mathrm{~V}$ (current: $3 \mathrm{~mA}$ ) for 2 days in the cathodic chamber of the two-chamber electrochemical reactor. The blue arrows in Figure 3 a represent cells damaged or disrupted by electric stress. Scale bars in the optical images represent $50 \mu \mathrm{m}$.

(a)

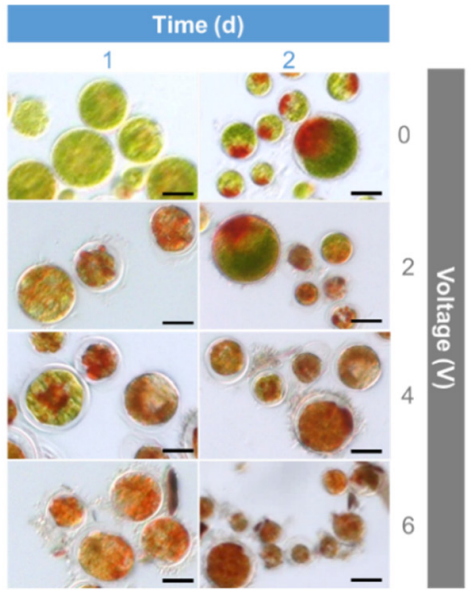

(b)

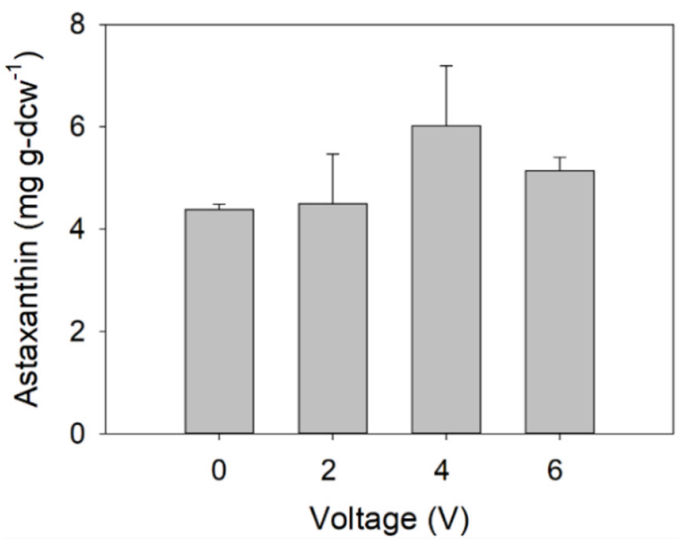

Figure 4. Effects of voltage intensity on the optical morphology (a) and astaxanthin content (b) of Haematococcus pluvialis cells in the anodic chamber of the two-chamber electrochemical reactor. The cellular astaxanthin levels were analyzed after the 2 day treatment. Scale bars in the optical images represent $15 \mu \mathrm{m}$.

The anodic stimulation results (Figure 4) further suggested that algal astaxanthin induction is highly dependent on the current intensity and duration of treatment. Currentduration relationships and optimization (such as long treatment durations at low current intensities, short treatment durations at high current intensities, or a gradual increase/decrease in current intensity with the treatment duration) could be studied in greater detail in further investigation for designing practical induction processes. Of note, the response of microorganisms to electric current is strongly dependent on various bioelectrochemical parameters, such as electrode type/material, reactor design, electrolyte concentration, and the electron mediator used $[19,25,26]$. 


\section{3. $\mathrm{CV}$ Analysis}

To characterize the bioelectrochemical reactions occurring between the carbon electrode and the $H$. pluvialis cells, a cyclic voltammogram was constructed based on the reaction occurring in a single-chamber electrochemical reactor with three electrodes (i.e., counter, working, and reference) and analyzed using a potentiostat (Figure 5). Similar to that in the electric stimulation process described above, green vegetative $H$. pluvialis cells cultured for 5 days in the photobioreactor were tested. The current density-voltage relationship varied significantly in the presence of algal cells under the applied reduction/oxidation potentials. For the algal cells, both reduction and oxidation current densities showed an increasing trend relative to that in the cell-free solution (abiotic control) within the voltage range of -0.5 to $+0.5 \mathrm{~V}$ (vs. $\mathrm{Ag} / \mathrm{AgCl}$ ). Particularly, the oxidation current density increased only slightly (from +0.1 (abiotic) to $+0.15 \mu \mathrm{A} \mathrm{cm}{ }^{-2}$ (biotic)) at $+0.5 \mathrm{~V}$, whereas the reduction current density increased significantly (from -0.1 (abiotic) to $-0.4 \mu \mathrm{A} \mathrm{cm}{ }^{-2}$ (biotic)) at $-0.5 \mathrm{~V}$. This suggests that even at the same voltage, significantly different oxidation and reduction environments can be created for the algal cells (Figures 3 and 4). The lysis and degradation of H. pluvialis cells during the cathodic current treatment (Figure 3) might be attributed to the formation of strong ROS in excess at the carbon cathode. The in situ production of $\mathrm{H}_{2} \mathrm{O}_{2}$ via the cathodic $2 \mathrm{e}^{-}$oxygen reduction reaction (ORR, $\mathrm{O}_{2}+2$ $\left.\mathrm{H}^{+}+2 \mathrm{e}^{-} \rightarrow \mathrm{H}_{2} \mathrm{O}_{2}\right)$ generates potent hydroxyl radicals $(\cdot \mathrm{OH})$, which can damage algal cells $[19,27]$. Specifically, carbon-based electrodes have been reported to effectively induce the $2 \mathrm{e}^{-}$ORR reaction [28].

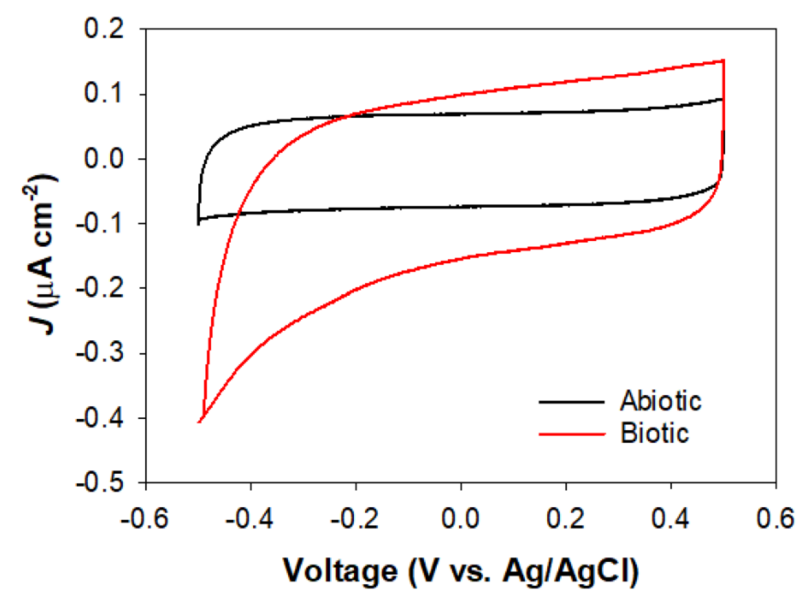

Figure 5. Cyclic voltammograms of the carbon electrode in the presence (biotic, red line) and absence (abiotic, black line) of Haematococcus pluvialis cells in a single-chamber electrochemical reactor with three electrodes. The scan rate was $10 \mathrm{mV} \mathrm{s}^{-1}$.

Figure 6 shows a hypothetical model for electric treatment of $H$. pluvialis in the twochamber bioelectrochemical system. Only a limited number of studies have been conducted on the electric treatment of microalgae, and detailed bioelectrochemical mechanisms are yet to be identified $[18,19,26,29]$. Electrical stimulation can be used to induce the synthesis of various microbial products biologically by electron transfer from the electrode or non-biologically by oxidizing chemicals generated from the electrodes [25,30]. Biological stimulation involves the direct interaction between membrane-associated enzymes and the electrode surface or the indirect transfer of electrons to the microorganism through electron mediators such as hydrogen. As a non-biological stimulant, ROS is known to induce the biosynthesis of neutral lipids and/or astaxanthin in various algal species, including Chlorella and Haematococcus [2,19]. The characterization and identification of the mechanism underlying the electric stimulation of astaxanthin production in H. pluvialis should be investigated in future studies. 


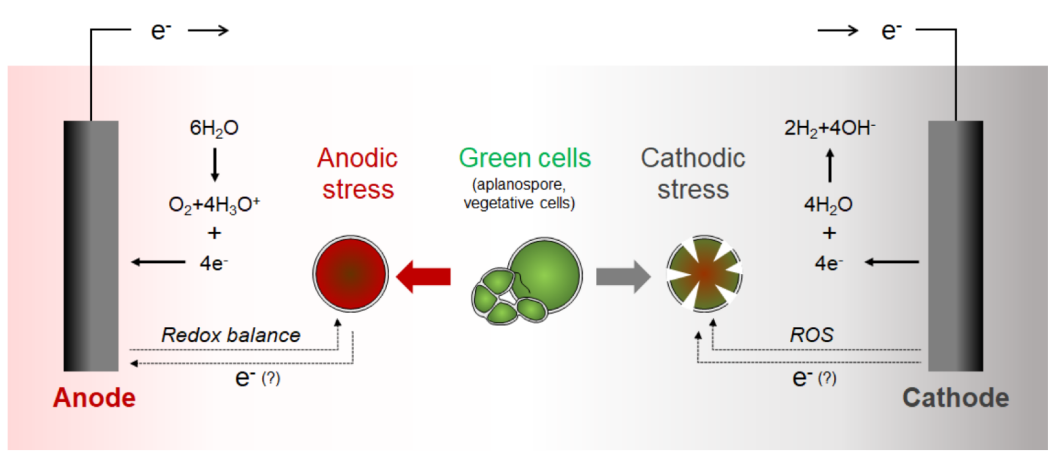

Figure 6. Simple hypothetical schematic of the electric treatment of Haematococcus pluvialis in the two-chamber bioelectrochemical system. ROS, reactive oxygen species.

\section{Conclusions}

The electro-treatment of $H$. pluvialis cells for astaxanthin induction in the two-chamber bioelectrochemical system was found to be highly dependent on cathodic (reduction) and anodic (oxidation) current conditions. Cathodic current treatment led to significant lysis and breakage of algal cells, even when a low voltage ( $2 \mathrm{~V}$; current, $3 \mathrm{~mA})$ was applied. In contrast, astaxanthin biosynthesis was induced successfully in H. pluvialis cells using anodic current treatment, with approximately $36.9 \%$ improvement achieved compared to that in the control. This was also accompanied by distinct morphological changes in the cells. Cyclic voltammetry analysis showed that the oxidation and reduction environments were significantly different even at the same voltage. This study suggests that electrochemical stimulation can serve as a unique method for promoting astaxanthin accumulation in H. pluvialis. However, for practical applications, extensive research, including the characterization of the precise bioelectrochemical mechanisms, as well as the optimization of process components, such as the reactor, electrode material, and electron mediator, is necessary.

Author Contributions: Conceptualization, Y.-K.O. and S.-Y.L.; Methodology, H.-N.F., S.-Y.L., S.-A.C. and J.-Y.L.; Investigation, H.-N.F. and S.-Y.L.; Resources, J.-S.L.; Supervision, Y.-K.O. and J.-S.L.; Writing-original draft preparation, H.-N.F. and S.-Y.L.; Writing-review and editing, Y.-K.O. and B.-L.K.; Funding acquisition, Y.-K.O. All authors have read and agreed to the published version of the manuscript.

Funding: This work was supported by a 2-Year Research Grant of Pusan National University.

Institutional Review Board Statement: Not applicable.

Informed Consent Statement: Not applicable.

Data Availability Statement: Not applicable.

Conflicts of Interest: The authors declare no conflict of interest.

\section{References}

1. Kim, D.Y.; Vijayan, D.; Praveenkumar, R.; Han, J.I.; Lee, K.; Park, J.Y.; Chang, W.S.; Lee, J.S.; Oh, Y.K. Cell-wall disruption and lipid/astaxanthin extraction from microalgae: Chlorella and Haematococcus. Bioresour. Technol. 2016, 199, 300-310. [CrossRef] [PubMed]

2. Shah, M.M.R.; Liang, Y.; Cheng, J.J.; Daroch, M. Astaxanthin-producing green microalga Haematococcus pluvialis: From single cell to high value commercial products. Front. Plant Sci. 2016, 7, 531. [CrossRef]

3. Lee, S.Y.; Cho, J.M.; Chang, Y.K.; Oh, Y.-K. Cell disruption and lipid extraction for microalgal biorefineries: A review. Bioresour. Technol. 2017, 244, 1317-1328. [CrossRef]

4. Poonkum, W.; Powtongsook, S.; Pavasant, P. Astaxanthin induction in microalga H. pluvialis with flat panel airlift photobioreactors under indoor and outdoor conditions. Prep. Biochem. Biotechnol. 2015, 45, 1-17. [CrossRef]

5. Han, D.; Li, Y.; Hu, Q. Astaxanthin in microalgae: Pathways, functions and biotechnological implications. Algae 2013, $28,131-147$. [CrossRef]

6. Noh, M.H.; Cha, S.; Kim, M.; Jung, G.Y. Recent advances in microbial cell growth regulation strategies for metabolic engineering. Biotechnol. Bioprocess. Eng. 2020, 25, 810-828. [CrossRef] 
7. Liyanaarachchi, V.C.; Nishshanka, G.K.S.H.; Premaratne, R.G.M.M.; Ariyadasa, T.U.; Nimarshana, P.H.V.; Malik, A. Astaxanthin accumulation in the green microalga Haematococcus pluvialis: Effect of initial phosphate concentration and stepwise/continuous light stress. Biotechnol. Rep. 2020, 28, e00538. [CrossRef] [PubMed]

8. Zhang, W.-W.; Zhou, X.-F.; Zhang, Y.-L.; Cheng, P.-F.; Ma, R.; Cheng, W.-L.; Chu, H.-Q. Enhancing astaxanthin accumulation in Haematococcus pluvialis by coupled light intensity and nitrogen starvation in column photobioreactors. J. Microbiol. Biotechnol. 2018, 28, 2019-2028. [CrossRef]

9. Oslan, S.N.H.; Shoparwe, N.F.; Yusoff, A.H.; Rahim, A.A.; Chang, C.S.; Tan, J.S.; Oslan, S.N.; Arumugam, K.; Ariff, A.B.; Sulaiman, A.Z.; et al. A Review on Haematococcus pluvialis bioprocess optimization of green and red stage culture conditions for the production of natural astaxanthin. Biomolecules 2021, 11, 256. [CrossRef]

10. Kiperstok, A.C.; Sebestyén, P.; Podola, B.; Melkonian, M. Biofilm cultivation of Haematococcus pluvialis enables a highly productive one-phase process for astaxanthin production using high light intensities. Algal Res. 2017, 21, 213-222. [CrossRef]

11. Giannelli, L.; Yamada, H.; Katsuda, T.; Yamaji, H. Effects of temperature on the astaxanthin productivity and light harvesting characteristics of the green alga Haematococcus pluvialis. J. Biosci. Bioeng. 2015, 119, 345-350. [CrossRef]

12. Hong, M.-E.; Hwang, S.K.; Chang, W.S.; Kim, B.W.; Lee, J.; Sim, S.J. Enhanced autotrophic astaxanthin production from Haematococcus pluvialis under high temperature via heat stress-driven Haber-Weiss reaction. Appl. Microbiol. Biotechnol. 2015, 99, 5203-5215. [CrossRef]

13. Harker, M.; Tsavalos, A.J.; Young, A.J. Factors responsible for astaxanthin formation in the Chlorophyte Haematococcus pluvialis. Bioresour. Technol. 1996, 55, 207-214. [CrossRef]

14. Kou, Y.; Liu, M.; Sun, P.; Dong, Z.; Liu, J. High light boosts salinity stress-induced biosynthesis of astaxanthin and lipids in the green alga Chromochloris zofingiensis. Algal Res. 2020, 50, 101976. [CrossRef]

15. Kim, Y.-E.; Matter, I.A.; Lee, N.; Jung, M.; Lee, Y.-C.; Choi, S.-A.; Lee, S.Y.; Kim, J.R.; Oh, Y.-K. Enhancement of astaxanthin production by Haematococcus pluvialis using magnesium aminoclay nanoparticles. Bioresour. Technol. 2020, 307, 123270. [CrossRef]

16. Grewe, C.; Griehl, C. Time- and media-dependent secondary carotenoid accumulation in Haematococcus pluvialis. Biotechnol. J. 2008, 3, 1232-1244. [CrossRef]

17. Choi, Y.Y.; Joun, J.M.; Lee, J.; Hong, M.E.; Pham, H.-M.; Chang, W.S.; Sim, S.J. Development of large-scale and economic pH control system for outdoor cultivation of microalgae Haematococcus pluvialis using industrial flue gas. Bioresour. Technol. 2017, 244, 1235-1244. [CrossRef] [PubMed]

18. Kim, J.Y.; Lee, C.; Jeon, M.S.; Park, J.; Choi, Y.E. Enhancement of microalga Haematococcus pluvialis growth and astaxanthin production by electrical treatment. Bioresour. Technol. 2018, 268, 815-819. [CrossRef] [PubMed]

19. Choi, S.-A.; Lee, S.Y.; Lee, J.; Cho, J.M.; Lee, J.-S.; Kim, S.W.; Kim, D.-Y.; Park, S.-K.; Jin, C.-S.; Oh, Y.-K. Rapid induction of edible lipids in Chlorella by mild electric stimulation. Bioresour. Technol. 2019, 292, 121950. [CrossRef] [PubMed]

20. Pick, U.; Zarka, A.; Boussiba, S.; Davidi, L. A hypothesis about the origin of carotenoid lipid droplets in the green algae Dunaliella and Haematococcus. Planta 2019, 249, 31-47. [CrossRef]

21. Praveenkumar, R.; Lee, K.; Lee, J.; Oh, Y.-K. Breaking dormancy: An energy-efficient means of recovering astaxanthin from microalgae. Green Chem. 2015, 17, 1226-1234. [CrossRef]

22. Choi, S.-A.; Jeong, Y.; Lee, J.; Huh, Y.H.; Choi, S.H.; Kim, H.-S.; Cho, D.-H.; Lee, J.-S.; Kim, H.; An, H.-R.; et al. Biocompatible liquid-type carbon nanodots (C-paints) as light delivery materials for cell growth and astaxanthin induction of Haematococcus pluvialis. Mater. Sci. Eng. C 2020, 109, 110500. [CrossRef] [PubMed]

23. Moon, G.; Lee, N.; Kang, S.; Park, J.; Kim, Y.-E.; Lee, S.-A.; Chitumalla, R.K.; Jang, J.; Choe, Y.; Oh, Y.-K.; et al. Hydrothermal synthesis of novel two-dimensional $\alpha$-quartz nanoplates and their applications in energy-saving, high-efficiency, microalgal biorefineries. Chem. Eng. J. 2020, 127467. [CrossRef]

24. Imamoglu, E.; Dalay, M.C.; Sukan, F.V. Influences of different stress media and high light intensities on accumulation of astaxanthin in the green alga Haematococcus pluvialis. New Biotechnol. 2009, 26, 199-204. [CrossRef] [PubMed]

25. Oh, Y.-K.; Hwang, K.-R.; Kim, C.; Kim, J.R.; Lee, J.-S. Recent developments and key barriers to advanced biofuels: A short review. Bioresour. Technol. 2018, 257, 320-333. [CrossRef]

26. La, H.-J.; Choi, G.-G.; Cho, C.; Seo, S.-H.; Srivastava, A.; Jo, B.-H.; Lee, J.-Y.; Jin, Y.-S.; Oh, H.-M. Increased lipid productivity of Acutodesmus dimorphus using optimized pulsed electric field. J. Appl. Phycol. 2016, 28, 931-938. [CrossRef]

27. Liang, J.; Tang, D.; Huang, L.; Chen, Y.; Ren, W.; Sun, J. High oxygen reduction reaction performance nitrogen-doped biochar cathode: A strategy for comprehensive utilizing nitrogen and carbon in water hyacinth. Bioresour. Technol. 2018, 267, 524-531. [CrossRef]

28. Özcan, A.; Şahin, Y.; Savaş Koparal, A.; Oturan, M.A. Carbon sponge as a new cathode material for the electro-Fenton process: Comparison with carbon felt cathode and application to degradation of synthetic dye basic blue 3 in aqueous medium. J. Electroanal. Chem. 2008, 616, 71-78. [CrossRef]

29. Wu, Y.; Guan, K.; Wang, Z.; Xu, B.; Zhao, F. Isolation, identification and characterization of an electrogenic microalgae strain. PLoS ONE 2013, 8, e73442. [CrossRef]

30. Lee, S.Y.; Oh, Y.-K.; Lee, S.; Fitriana, H.N.; Moon, M.; Kim, M.-S.; Lee, J.; Min, K.; Park, G.W.; Lee, J.-P.; et al. Recent developments and key barriers to microbial $\mathrm{CO}_{2}$ electrobiorefinery. Bioresou. Technol. 2021, 320, 124350. [CrossRef] 